\title{
Customer Satisfaction Assessment Using the SERVQUAL Model
}

\author{
Martin Mabeifam Ujakpa ${ }^{1}$, Jonathan Fundisi ${ }^{2}$, Laizah Mutasa ${ }^{3}$, Victoria Kaleinasho Lazarus ${ }^{1}$, \\ Naemi Mutuna Uushini ${ }^{1}$, Timoteus Sheepo ${ }^{1}$, Joana Eshun ${ }^{4}$ \\ ${ }^{1}$ Department of Information Technology, Faculty of Information Technology \& Systems Development, International University of \\ Management, Windhoek, Namibia \\ ${ }^{2}$ Department of Network \& Security, Faculty of Information Technology \& Systems Development, International University of Management, \\ Windhoek, Namibia \\ ${ }^{3}$ Department of Software Development, Faculty of Information Technology \& Systems Development, International University of \\ Management, Windhoek, Namibia \\ ${ }^{4}$ Jamodja University of Zambia, Windhoek, Namibia
}

\section{Email address:}

ujakpamabeifam@gmail.com (M. M. Ujakpa),j.fundisi@ium.edu.na (J. Fundisi), s.mutasa@ium.edu.na (L. Mutasa), v.lazarus@ium.edu.na (V. K. Lazarus),n.uushini@ium.edu.na (N. M. Uushini), t.sheepo@ium.edu.na (T. Sheepo), joanaeshun10@gmail.com (J. Eshun)

\section{To cite this article:}

Martin Mabeifam Ujakpa, Jonathan Fundisi, Laizah Mutasa, Victoria Kaleinasho Lazarus, Naemi Mutuna Uushini, Timoteus Sheepo, Joana Eshun. Customer Satisfaction Assessment Using the SERVQUAL Model. Science Journal of Business and Management.

Vol. 5, No. 5, 2017, pp. 194-198. doi: 10.11648/j.sjbm.20170505.13

Received: August 16, 2017; Accepted: August 28, 2017; Published: December 15, 2017

\begin{abstract}
The main objective of this study is to examine customer satisfaction in the banking sector using the SERVQUEL model and Ecobank Ghana Limited in Ghana as a case study. The research employed the quantitative research approach. Using a sample size of 150, data was collected and analysed. The research revealed that expectations of customers exceeded their perceptions. The interpretation of this result using the disconfirmation theory is that customers are generally not satisfied with the quality of service they receive from the bank. The conclusion drawn in this regard is that, Ecobank Ghana Limited is not fully meeting the expectations of their customers and hence need to do more to improve its service quality as a means of satisfying their customers so as to remain competitive. The research population was restricted to three Ecobank branches: all in one township and hence the results of the study cannot be generalized. Future studies should therefore look at conducting a countrywide study.
\end{abstract}

Keywords: SERVQUEL, Customer Satisfaction, Expectation Disconfirmation Theory, Customer Expectation

\section{Introduction}

Businesses today are always looking for ways to ensure that they stay ahead of the pack. No business wants to stay behind and hence the continuous strive to gain competitive advantage. A business is said to have competitive advantage when it is able to secure an edge over its competitors in relation to such factors as securing customers and defending against competitive forces. Competitive advantage means placing one's business in position that is ahead of its rival in their given sector. Several approaches have been resorted to for competitive advantage. These include: production of high quality goods and services, superior customer service provision, establishing business at convenient locations as well as ensuring that customers get value for money [9].

Banks in Ghana just like those around the globe have developed and introduced several measures to improve their performance. These include diverse technology based products and services such as internet banking and the employment of various communication tools and mediums for marketing their services. The challenge with this approach is that immediately one Bank introduces a change, its rival either replicates them or introduces improved version. As a result, Banks have resorted to customer related 
factors to stay ahead of their rivals. This study seeks to examine customer satisfaction in the banking sector using the SERVQUEL model.

As a result, Banks have resorted to customer relatedfactors to stay ahead of their rivals. The customer relatedfactors include tangibility, reliability, empathy, responsiveness and assurance. According to Kumar et al. [13], introduction of the above factors improves customer loyalty and retention, thereby giving a bank competitive edge over others. To [14], empathy, tangibility, responsiveness, reliability, and assurance significantly predict customer satisfaction. In the case of Ghana, there is little studies on how service quality practices may lead to customer satisfaction in in the banking industry [12]. There is therefore the need to ascertain how service quality leads to customer satisfaction. One of the few studies on service quality in the banking industry was conducted using Ghana Commercial Bank [12] and a target population from the capital town of Ghana. Hence the findings of that study could be skewed towards other factors within that particular bank or the geographical location of the target population. Therefore adopting the SERVQUEL model, using a different bank (Ecobank) and different population target, this study seeks to examine customer satisfaction.

\section{Literature Review}

In today's highly competitive banking industry, customer satisfaction is considered as the bedrock of success. Marketing researchers generally agree that satisfaction is a response to consumption related experiences. Customers who are satisfied tell others about their experiences: word of mouth (WOM) advertising [10]. Unlike the past, modern marketing philosophies are all hinged around customer satisfaction. Nowadays marketing activities are centred on identifying customers' needs and how an organisation can effectively meet these needs satisfactorily.

According to [3], customer satisfaction is the difference between a customer's anticipation of a desired result from a purchase and the actual benefits derived from the use of the purchase. This definition sees customer satisfaction is an end result of a service enjoyed by the customer. However the definition of [4] sees customer satisfaction as a measure of customer's behaviour as a response of services received. According to [4], customer satisfaction is achieved if customers remain loyal and repurchase product or service.

Theories of customer satisfaction include cognitive dissonance theory, expectation disconfirmation theory and SERVQUEL model. Cognitive dissonance theory states that consumers assess the performance of a product or service based on a mental assessment of expectation and the perceived outcome of the product's usage [8]. This leads to some form of dissonance. To manage the dissonance, consumers correct their perception about the product to align with the expectation [1].

Expectation Disconfirmation theory states that consumer satisfaction is a function of the size and direction of the disconfirmation as experienced through a comparison of the actual service performance and the expectation performance [5]. This theory is illustrated in figure 1 below.

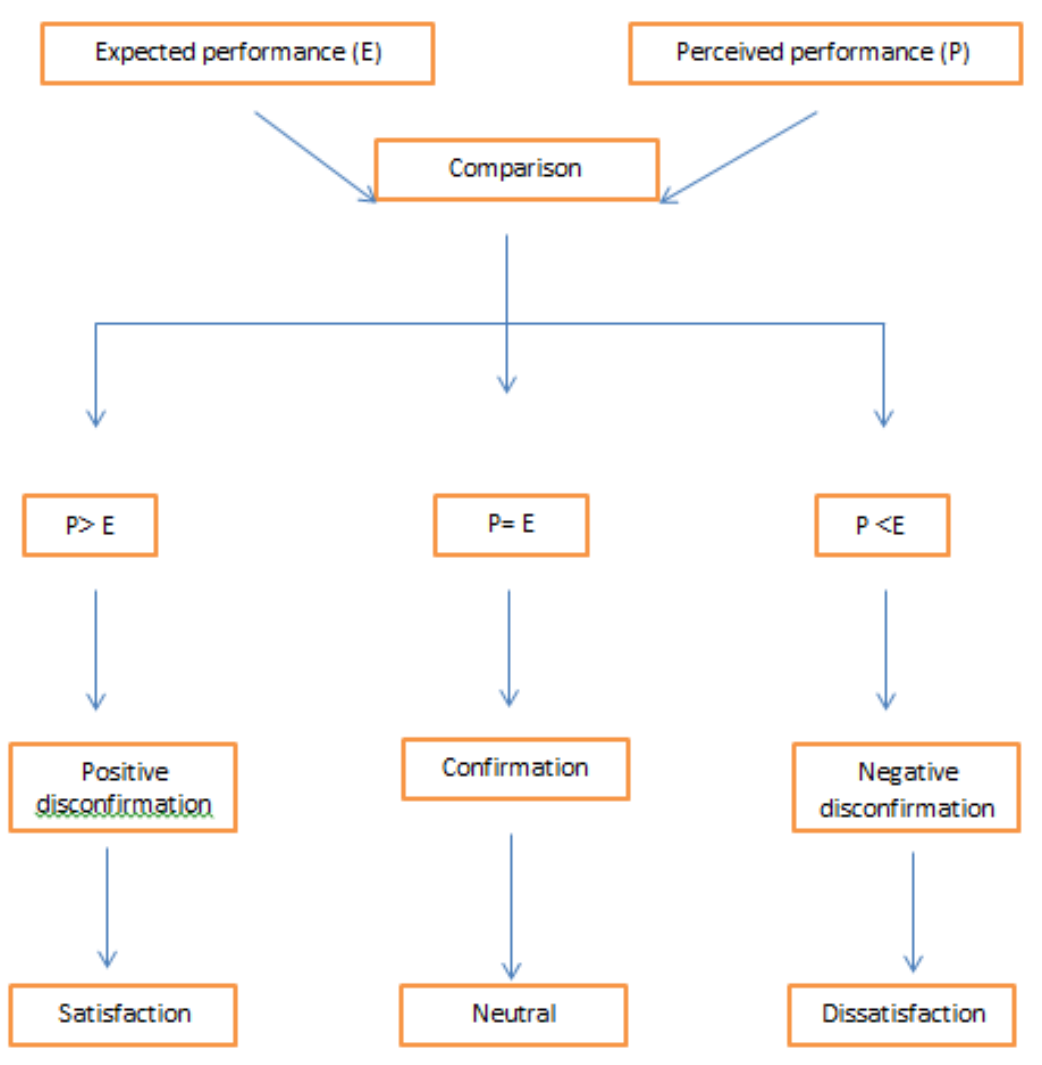

Figure 1. Expectation Disconfirmation Theory. 
SERVQUAL model assess the level of service quality of service providers based on five elements of service namely: tangibles, reliability, responsiveness, assurance and empathy.

\section{Research Methodology}

The research design employed for this study is the quantitative approach. Data used for the study include Primary and Secondary data. Instruments employed in collecting the primary data include questionnaires, interviews and observation. Secondary data was obtained by a review of literature in relation to the subject under discussion and also data from Ecobank's records. The study population is made up of 1600 customers of the three branches of Ecobank Ghana Limited in Takoradi. This number is made up of One Hundred (100) Corporate Bankers, Eight Hundred (800) Small and Medium Scale bankers and Seven Hundred (700) personal bankers [6].

A total of 150 customers were however conveniently sampled for this study using simple random sampling method. In order to obtain a fair representation of each customer group, the various classes of customers were stratified into their account types. The number of customers selected from each strata was then determined as the product of the ratio of the number of customers in each class to the total number of customers by One Hundred and Fifty (150). The respective numbers obtained were as follows: 10 corporate bankers, 75 SME bankers and 65 individual banking customers. Reliability and validity was catered for, by designing research instrument such that respondent's responses addressed the study. Also a pilot test was carried out on the study instruments using customers.

\section{Discussion}

Of the 150 customers targeted for the study, there was a response rate of $89 \%$ (134 customers responding). $70.1 \%$ (94 respondents) had banked with Ecobank for more than 5 years: as much as to 16 years. Only $29.1 \%$ (40 respondents) banked with the bank less than five years.

As in table 1 , mean and standard deviation was computed on tangibility factors. Mean scores on physical facilities being good and nice yielded 3.42 and 4.36 for perception and expectation respectively. That of the neatness and appealing nature of the bank staff yielded 3.37 and 4.50 for perception and expectation respectively. That current status of technology and electronics in the bank yielded 3.70 and 4.75 for perception and expectation respectively. The total mean score of customers' perception and expectations yielded 10.49 and 13.61 for perception and expectation respectively. This implies that the perceived performance $(\mathrm{P})$ of the tangibles of the bank was below the expected performance (E): that is $\mathrm{P}<\mathrm{E}$. From the disconfirmation theory, $\mathrm{P}<\mathrm{E}$ is an indication of a negative disconfirmation: meaning customers were not satisfied or their expectations regarding the tangibles of the bank were not met. But considering the value difference between $\mathrm{P}$ and $\mathrm{E}$ (too very wide), it is concluded that the Bank needs to put just a little more effort into upgrading their tangible as a means of satisfying their customers.

Table 1. Assessment of Customer Perception and Expectation of the Tangibles of Ecobank.

\begin{tabular}{lccccc}
\hline \multirow{2}{*}{ Tangibles } & N & \multicolumn{2}{c}{ Perception (P) } & \multicolumn{2}{c}{ Expectation (E) } \\
\cline { 2 - 6 } & & Mean & Std Dev & Mean & Std Dev \\
\hline $\begin{array}{l}\text { Banks physical facilities } \\
\text { are good }\end{array}$ & 134 & 3.42 & .781 & 4.36 & .481 \\
$\begin{array}{l}\text { Bank staff will be neatly } \\
\text { appealing }\end{array}$ & 134 & 3.37 & .971 & 4.50 & .502 \\
$\begin{array}{l}\text { Technology and } \\
\text { electronic facilities are }\end{array}$ & 134 & 3.70 & .459 & 4.75 & .437 \\
$\begin{array}{l}\text { up to date } \\
\text { Total }\end{array}$ & & 10.49 & & 13.61 & \\
\hline
\end{tabular}

(Source: author, 2016)

When mean and standard deviation values computed on reliability factors (see in table 2), Ecobank delivering on its promises got a mean score of 3.04 and 4.69 for perception and expectation respectively. Those of the convenience of the banking hours mean scored 3.93 and 4.70 for perception and expectation respectively. Mean score of the bank's ability to provide error-free records is 3.19 and 4.81 for perception and expectation respectively. Total mean score of customers' perception and expectations is 10.16 and 14.20 respectively. This implied that the perceived performance of the tangibles of the Bank was below the expected performance, that is $\mathrm{P}<\mathrm{E}$. From the disconfirmation theory, $\mathrm{P}<\mathrm{E}$ is an indication of a negative disconfirmation meaning customers are not satisfied or their expectations regarding reliability nature of the Bank were not met. But the difference 4.04 gives an indication that the bank needs to put in more effort to present itself as reliable to customers.

Table 2. Assessment of Customer Perception and Expectation of the Reliability Nature of Ecobank.

\begin{tabular}{llllll}
\hline \multirow{2}{*}{ Reliability } & \multirow{2}{*}{ N } & \multicolumn{3}{c}{ Perception (P) } & \multicolumn{2}{c}{ Expectation (E) } \\
\cline { 3 - 6 } & & Mean & Std Dev & Mean & Std Dev \\
\hline $\begin{array}{l}\text { Bank will provide all } \\
\text { services as promised }\end{array}$ & 134 & 3.04 & .826 & 4.69 & .463 \\
$\begin{array}{l}\text { Bank operating hours will } \\
\text { be convenient to me }\end{array}$ & 134 & 3.93 & .494 & 4.70 & .459 \\
$\begin{array}{l}\text { Deliver error free records } \\
\text { and up to date records }\end{array}$ & 134 & 3.19 & .594 & 4.81 & .397 \\
\begin{tabular}{l} 
Total \\
\hline
\end{tabular} & & 10.16 & & 14.20 & \\
\hline
\end{tabular}

(Source: author, 2016)

On empathy factors as in table 3, mean scores obtained with respect to the fact that Ecobank is able to provide products that suits the needs of their customers were 2.91 and 4.65 for perception and expectation respectively. In terms of the customers' view on their interest been at the heart of Ecobank, the respective means scores were 2.93 and 4.22 for perception and expectation respectively. Mean scores of the ability of the bank to give individual customers attention were 3.14 and 4.40 for perception and expectation 
respectively. Total mean scores of customers' perception and expectations were 9.98 and 13.60 for perception and expectation respectively. This implied that the perceived performance of the tangibles of the bank was below the expected performance, that is $\mathrm{P}<\mathrm{E}$. From the disconfirmation theory, $\mathrm{P}<\mathrm{E}$ is an indication of a negative disconfirmation meaning customers do not feel that Ecobank is empathetic towards them. Considering the value difference of 3.62 that is significant, it's concluded that the bank needs to pay attention to its relationship with its customers.

Table 3. Assessment of Customer Perception and Expectation of the Empathetic Nature of Ecobank.

\begin{tabular}{llllll}
\hline \multirow{2}{*}{ Empathy } & \multirow{2}{*}{ N } & \multicolumn{3}{c}{ Perception (P) } & \multicolumn{2}{c}{ Expectation (E) } \\
\cline { 2 - 6 } & Mean & Std Dev & Mean & Std Dev \\
\hline $\begin{array}{l}\text { Bank will provide } \\
\text { products that best suits my } \\
\text { needs }\end{array}$ & 134 & 2.91 & .541 & 4.65 & .479 \\
$\begin{array}{l}\text { Bank will have my interest } \\
\text { at heart }\end{array}$ & 134 & 2.93 & .859 & 4.55 & .499 \\
$\begin{array}{l}\text { Bank staff will give me } \\
\text { individual attention }\end{array}$ & 134 & 3.14 & .577 & 4.40 & .491 \\
\begin{tabular}{l} 
Total \\
\hline
\end{tabular} & & 9.98 & & 13.60 & \\
\hline
\end{tabular}

(Source: author, 2016)

On the bank responsiveness as in table 4 below; mean scores for the bank staff willingness to assist whenever a customer is in need, is 3.86 and 4.75 for perception and expectation respectively. On the bank's ability to speedily assist customers, mean score is 3.69 and 4.65 for perception and expectation respectively. Total mean scores of customers' perception and expectations for responsiveness is 7.75 and 9.40 respectively. This implies that the perceived performance of the responsiveness of the bank was below the expected performance, that is $\mathrm{P}<\mathrm{E}$. From the disconfirmation theory, $\mathrm{P}<\mathrm{E}$ is an indication of a negative disconfirmation meaning customers do not feel that Ecobank is responsive towards their needs. Given that the difference was 1.95 that is insignificant, it can be concluded that the bank needs to put just a little more effort into upgrading their responsiveness.

Table 4. Assessment of Customer Perception and Expectation of the Responsiveness of Ecobank.

\begin{tabular}{llllll}
\hline \multirow{2}{*}{ Responsiveness } & \multirow{2}{*}{$\mathbf{N}$} & \multicolumn{2}{c}{ Perception (P) } & \multicolumn{2}{c}{ Expectation (E) } \\
\cline { 3 - 6 } & & Mean & Std Dev & Mean & Std Dev \\
\hline $\begin{array}{l}\text { Bank staff will be willing } \\
\text { to assist customers }\end{array}$ & 134 & 3.86 & .577 & 4.75 & .432 \\
$\begin{array}{l}\text { Provide quick service with } \\
\text { speed in solving problems }\end{array}$ & 134 & 3.69 & .554 & 4.65 & .479 \\
Total & & 7.55 & & 9.40 & \\
\hline
\end{tabular}

(Source: author, 2016)

On assuring nature of the bank and as in table 5 , the mean scores on bank staff having acquired the required knowledge needed to meet customer needs was 4.10 and 4.77 for perception and expectation respectively. On bank staff creating the feeling of confidence among customers, the respective means response was 3.47 and 4.70 for perception and expectation respectively. Mean scores of the ability of the bank to ensure the security of its customers is 4.12 and 4.80 for perception and expectation respectively. Total mean score of customers' perception and expectations is 11.69 and 14.27 for perception and expetation respectively. This implies that the perceived performance of the assuring nature of the bank was below the expected performance, that is $\mathrm{P}<\mathrm{E}$. From the disconfirmation theory, $\mathrm{P}<\mathrm{E}$ is an indication of a negative disconfirmation meaning Ecobank is not creating a feeling of assurance among its customers. Considering the difference of 3.62 , it gives an indication that Bank is doing well but has to put in extra effort to improve its assuring nature.

Table 5. Assessment of Customer Perception and Expectation of the Assuring Nature of Ecobank.

\begin{tabular}{lccccc}
\hline \multirow{2}{*}{ Assurance } & \multirow{2}{*}{ N } & \multicolumn{2}{c}{ Perception (P) } & \multicolumn{2}{c}{ Expectation (E) } \\
\cline { 3 - 6 } & & Mean & Std Dev & Mean & Std Dev \\
\hline $\begin{array}{l}\text { Bank staff will have all the } \\
\text { knowledge needed to }\end{array}$ & 134 & 4.10 & .640 & 4.77 & .423 \\
$\begin{array}{l}\text { assist me } \\
\begin{array}{l}\text { Staff behaviour will instil } \\
\text { confidence in me }\end{array}\end{array}$ & 134 & 3.47 & .501 & 4.70 & .455 \\
$\begin{array}{l}\text { Bank will have strong } \\
\text { security arrangements/feel } \\
\text { safe }\end{array}$ & 134 & 4.12 & .535 & 4.80 & .403 \\
Total & & 11.69 & & 14.27 & \\
\hline
\end{tabular}

(Source: author, 2016)

\section{Conclusion}

The results obtained above indicate that the expectations of customers exceeded their perceptions. The interpretation of this result using the disconfirmation theory is that customers are generally not satisfied with the quality of service they receive from Ecobank. The conclusion drawn in this regard is that, Ecobank Ghana Limited is not fully meeting the expectations of their customers and hence additional effort is required to improve its service quality as a means of satisfying its customers so as to remain competitive.

\section{Limitation and Recommendation}

This study was conducted from three Ecobank branches: all in one township and hence the results of the study cannot be generalized. Future studies should therefore look at conducting a countrywide study.

\section{References}

[1] Anderson et al. (2006) Customer satisfaction, market share and profitability: finding from Sweden. Journal of Marketing, 58, June.

[2] Anderson, R. E. (2005). Consumer dissatisfaction: The effect of disconfirmed expectancy on Perceived Product Performance. Journal of Marketing Research, 10 February: 38-44.

[3] Churchill and Suprenant. (2007). An Investigation Into The Determinant Of Customer Satisfaction. Journal marking science. 19(4). 
[4] Eckert, S. G. (2007). Inventory Management and Its Effects on Customer Satisfaction. Journal of Business and public Policy. (1), 1-2.

[5] Ekinci Y. \& Sirakaya E. (2004). An Examination of the Antecedents and Consequences of Customer Satisfaction. In: Crouch G. I., Perdue R. R., Timmermans H. J. P., \& Uysal M. Consumer Psychology of Tourism, Hospitality and Leisure. Cambridge, MA: CABI Publishing, 189-202.

[6] Ecobank (2014). Customer Population. Ecobank Gh Ltd. Takoradi, Ghana.

[7] Fornell, C. (2006), A National Customer Satisfaction Barometer: The Swedish Experience. Journal of Marketing, $56(1), 6-21$.

[8] Harvey \& M. Sherif (2007). Assimilation And Contrast Effects In Reaction To Communication And Attitude Change. Journal of Abnormal and Social Psychology, 55(7), 244-252.

[9] Porter, M. E. (2007), Competitive Advantage: Creating and Sustaining Superior Performance. The Free Press, New York.

[10] Siddiqi, K. O. (2010). Interrelations Between Service Quality
Attributes, Customer Satisfaction And Customer Loyalty In The Retail Banking Sector In Bangladesh. International Trade \& Academic Research Conference (ITARC), 1-26. London.

[11] Titko, J. and Lace, N. (2010). Customer Satisfaction and Loyalty in Latvian Retail Banking, Economics and Management, 15, 1031-1038.

[12] Cudjoe, A., G., Anim, P., A., Nyanyofio Joseph, G., N., T. (2015). Service Quality and Customer Satisfaction in the Ghanaian Banking Industry: A Case of Ghana Commercial Bank. European Journal of Business and Management, 7(3), 123-140.

[13] Kumar, M., Kee, F. T. \& Charles, V. (2010). Comparative Evaluation of Critical Factors in Delivering Service Quality of Banks: An Application of Dominance Analysis in Modified SERVQUAL Model. International Journal of Quality and Reliability Management, 27 (3), 351-377.

[14] Lau M., M., Cheung, R., Lam, Aris., Y., C. \& Chu, Y., Ting. (2013). Measuring Service Quality in the Banking Industry: A Hong Kong Based Study. Contemporary Management Research 9(3). 263-282. 